Journal of Southeast Asian

\title{
[Special Issue on SEA Demographics] Response - Sociological Questions to Consider
}

Yang Sao Xiong

University of California, Las Angeles, ysxiong07@gmail.com

Follow this and additional works at: https://docs.lib.purdue.edu/jsaaea

Part of the Sociology Commons

\section{Recommended Citation}

Xiong, Yang Sao (2008) "[Special Issue on SEA Demographics] Response - Sociological Questions to Consider," Journal of Southeast Asian American Education and Advancement: Vol. 3 : Iss. 1, Article 11. DOI: $10.7771 / 2153-8999.1107$

Available at: https://docs.lib.purdue.edu/jsaaea/vol3/iss1/11

This document has been made available through Purdue e-Pubs, a service of the Purdue University Libraries. Please contact epubs@purdue.edu for additional information.

This is an Open Access journal. This means that it uses a funding model that does not charge readers or their institutions for access. Readers may freely read, download, copy, distribute, print, search, or link to the full texts of articles. This journal is covered under the CC BY-NC-ND license. 


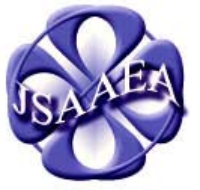

Volume 3

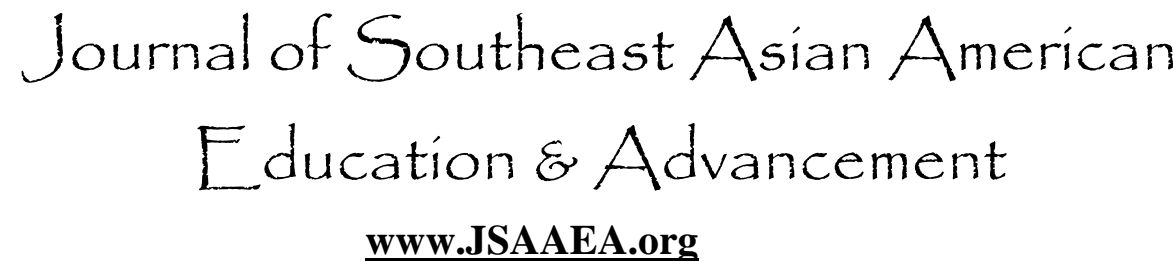

WWW.JSAAEA.org
A peer-reviewed

scholarly journal

published by the

National Association

for the Education \&

Advancement of

Cambodian, Laotian, and Vietnamese Americans (NAFEA)

\title{
Special Issue on Southeast Asian American Demographics
}

\section{Response-Sociological Questions to Consider}

\author{
Yang Sao Xiong \\ University of California, Las Angeles
}

I am delighted to see a report that provides a clear and concise description of group trends among Southeast Asian American (SEA) communities. I welcome the opportunity to comment on Dr. Mark Pfeifer's descriptive article, and below are some of my comments on it.

Overall, the ACS 2005 data suggest that all SEA groups are making progress, in terms of economics and education, but that it can take several years or decades for significant changes to occur. For instance, in the case of Hmong, the poverty rate has been cut in half between 1990 and 2005 (Pfiefer \& Lee, 2004). This represents a period of 15 years. Given the pre-migration experiences of Hmong, nearly all of whom entered the United States as political refugees, 15 years is not surprising and, in my opinion, should be expected. After all, it takes years even for U.S. born, English-speaking individuals to acquire the basic educational credentials, language skills, and work experiences to find employment and secure an independent living.

However, what is unclear is whether all cohorts of Hmong refugees have achieved the same or a similar rate of progress within 15 years of their initial resettlement. Furthermore, it is important to ask questions about where in the United States these communities resettled and which cohorts or generational cohorts made what kinds of progress over the past three decades. Here I am suggesting that a group's time of arrival and place of resettlement may play determining roles with regard to its poverty rates and other forms of progress besides economic and educational attainment. Because the ACS reports aggregated data on entire ethnic groups rather than generational cohorts within and between groups, further comparative research needs to be done to examine where and when progress has been made, by whom, and how much progress.

The ACS 2005 and Census 2000 data suggest that each of the four SEA communities has undergone changes in population size (increased), income (increased), poverty rates (decreased), home ownership rate (increased), and educational attainment (increased). Given these communities' relatively short length of residence in the United States, these changes provide hope but also raise questions. On the face of it, these changes suggest that all SEA groups can expect to attain higher standards of living as time passes. The moderate increase in educational attainment, especially within the bachelors and graduate levels, suggests that there are real, albeit limited opportunities for SEA persons to attend, advance, and graduate from school. Given the credential-based society in which we live, a sustained increase in educational levels among all SEA groups may bring about increased occupational opportunities.

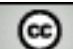

SORERIGHISRESERVEDReaders are free to copy, display, and distribute this article, as long as the work is attributed to the author(s) and the Journal of Southeast Asian American Education \& Advancement, it is distributed for noncommercial purposes only, and no alteration or transformation is made in the work. More details of this Creative Commons license are available at http://creativecommons.org/licenses/by-nc-nd/3.0/. All other uses must be approved by the author(s) or JSAAEA. 
Nevertheless, because of the immense heterogeneity that exists within ethnic groups, it is less clear from the aggregated data how individuals, families and neighborhoods of families will fare in the next five to ten years. Will increased education translate into greater occupational and income opportunities for Southeast Asian individuals and SEA as a group? Or will SEA communities continue to experience "glass ceilings" as their occupations remain stratified by race, gender, perceived cultural difference, etc.? Moreover, without further and sustained research, we can only speculate on the relationship between these changes (for example, increased income or homeownership) and the change in a group's "standard of living."

Although income, occupation, educational attainment, and homeownership are often used as indicators of social mobility, it is far from clear what direct relationship these factors, whether individually or in combination have for a group's long-term social mobility. For instance, an increase in a group's average income may be the direct result of families having more and multiple members employed, rather than a result of greater access to higher-paid occupations or occupations of high prestige and authority. Given that the prices of basic, necessary commodities, such as gas and food have gone up significantly in recent years, even a moderate increase in families' incomes may barely help them maintain self-sufficiency. Moreover, in the case of some families, including some Hmong American families, homeownership could spell great long-term financial burden or even bankruptcy. Looking at homeownership rate alone misses the emotional, social and economic costs of maintaining homeownership. In short, it is not clear what major changes - changes that fundamentally alter SEA's social, educational, and political positions within America's economy and society-will occur as a result of recent increases in SEA's educational levels, income levels, homeownership, etc. In my opinion, it is plausible that significant gaps could remain between the better-off and the working poor within SEA communities even as the average socioeconomic standing of a group increases.

Furthermore, the increase in the SEA population could have a number of important implications for these communities. I think that one implication of the population increase is potentially an increase in SEA's political participation and political clout. Of course, further research should be done to examine how increases in the number of eligible and registered SEA voters might affect political mobilization and participation among SEA communities. (I know of few reports that provide figures on SEA's political participation, voting behavior, etc.). Future research should also examine how Southeast Asian grassroots organizations mobilize, interact, negotiate with and rely on each other during political struggles and local and state political campaigns.

Although the data indicate that SEA communities, especially Vietnamese, can now be found in most of the 50 states, it is clear that all four groups of SEA remain mostly highly concentrated in a few states (California, Texas, Minnesota, Washington). It would be important to investigate the changes in SEA communities' places of residence since their arrival. What kinds of dissimilarity indices are found in the areas where SEA communities are concentrated? What do these indices tell us about SEA communities' past and present residential integration or segregation? Data collected through in-depth surveys and ethnographic case studies could help shed light on SEA's experiences with residential segregation, crime, violence, forms of discrimination and compromise. Indeed, further studies should be done on how SEA communities have formed and maintained themselves in times of crisis or social disruption during the past three to four decades; these studies may provide useful information about SEA's challenges and prospects for progress. 
What are some remaining challenges for Southeast Asian communities and the institutions which serve them? There are many, new and old challenges. In this section, I point out two challenges: (1) That SEA students, especially Vietnamese and Hmong in California's public schools are disadvantaged by current state and district policies of classifying, testing, and tracking English Learners; and (2) that Hmong American students confront a multitude of socioeconomic obstacles to educational advancement.

In California, Vietnamese and Hmong-speaking students remain the second and third largest groups of English Learners, trailing behind only Spanish-speakers. (Spanish speakers compose $85 \%$ of all English Learners). A significant number of Cambodian/Khmer and, to a lesser extent, Lao-speaking students also remain classified as English Learners in California. As Min Zhou and I have discussed elsewhere, there are serious disadvantages associated with being identified and classified as a linguistic minority student. We argue that the current state policies of classifying, testing, and tracking of linguistic minority students, including a vast majority who are U.S.-born, seriously disadvantage SEA students. These processes deny English Learners equitable access to quality programs, college preparatory curricula, credentialed teachers, and opportunities to pursue higher education (Xiong \& Zhou, 2006). Because a remarkable percentage of Hmong, Lao, Cambodian and Vietnamese speaks, or has been identified as speaking a language other than English, current state education policies and school district practices will continue to have tremendous consequences for SEA students' learning opportunities and advancement. As we begin a new school year, I believe that the legalized practices of classification, testing, and tracking of English learner students will remain some of the most difficult challenges confronting SEA students in K-12 public schools throughout California and other states with significant concentrations of SEA communities. I urge everyone to consider these issues and to participate in identifying their consequences for SEA students.

Dr. Pfeifer's report indicates that compared to the other three SEA groups and the U.S. average, Hmong Americans fared less well on several key indicators of socioeconomic status. Hmong Americans have a relatively younger population, larger household and family size, lower household and family median income, higher proportion living in poverty, and higher proportion of disabled 65 year-olds or older. The data indicate further that only a small percentage of Hmong (25 year-olds) has attained Bachelor's and graduate or professional degrees. Some of these demographic and social factors may help explain, in part, why only about 4.8 percent of Hmong (16 years and over) worked in professional, scientific, and management industries while 17.8 percent worked in educational services and health care and social assistance. In any case, these statistics suggest that compared to the other SEA groups sampled, Hmong American students have fewer resources with which to overcome disadvantages.

Overall, the figures in the ACS appear accurate. I think they are a fair representation of the sampled Southeast Asian American communities. Obviously, there are other SEA ethnic groups, such as Thai and Mien, missing from this dataset/report. Indeed, depending on our definition of "Southeast Asian Americans," other groups may or may not be represented.

I want to point out that the figures on speaking English (Table 8) and speaking a nonEnglish language (Table 9) can be misleading. Table 8 could be improved by reporting all response categories of English speaking ability (\% speaking English very well, well, not well, not at all, etc.), rather than reporting only the category "Speak English Less Than Very Well." Table 9 could be (mis)interpreted as indicating that the SEA groups speak exclusively nonEnglish languages at home. However, SEA households rarely speak only a non-English 
language; the more common practice is that SEA young people and, to a lesser extent, adults speak their native language along with English.

The ACS 2005's Accuracy of the Data report (U.S. Census Bureau, 2005a) does not indicate whether any attempt has been made to translate the survey instruments in languages other than English. Given that the surveys mailed out are written in English (U.S. Census Bureau, 2005b), this could have important implications on response rates, the accuracy of the responses, and the selectivity of the sample. There is the possibility of a biased sample: perhaps only SEA households with persons who speak English returned the completed surveys. Conversely, SEA households with only non-English speaking couples or households where parents and young children are not able to read or write English well would be missed by the ACS.

Given the work I do as a student of sociology, I agree with Dr. Pfeifer that having both qualitative and quantitative studies of multiple sites/regions of SEA communities would be a useful resource. Longitudinal data on each ethnic group would also be very useful for examining questions about changes in SEA communities' opportunities, social networks, political and religious attitudes and behavior, etc. Since in some instances, Vietnamese have experienced or attained outcomes quite different from those of the other three SEA groups, research that explores structural causes of social change by separately investigating SEA groups' historical and present circumstances would be quite appropriate. Given the tremendous complexities and heterogeneity found within groups at any given point in time, I think that using ethnographic alongside quantitative methods would be an appropriate and effective way to gather/generate data needed to answer questions about social processes and group outcomes. Studies that strive for causal explanations of group outcomes would require the use of even clearer concepts, more detailed, time and place-specific data, and informed, imaginative theorizing.

\section{References}

Pfeifer, M. E., \& Lee, S. (2004). Hmong population, demographic, socioeconomic and educational trends in the 2000 Census. In Hmong Census publication: Data and analysis (pp. 3-11). Saint Paul, MN and Washington, DC: Hmong Cultural and Resource Center and Hmong National Development.

U.S. Census Bureau (2005a). Accuracy of the data. Washington, DC: U.S. Department of Commerce. Retrieved June 2, 2008 from http://www.census.gov/acs/www/Downloads/ ACS/accuracy2005.pdf

U.S. Census Bureau (2005b). The American Community Survey. Washington, DC: U.S. Department of Commerce. Retrieved June 2, 2008 from http://www.census.gov/acs/ www/Downloads/SQuest05.pdf

Xiong, Y. S. \& Zhou, M. (2006). Structuring inequity: How California selectively tests, classifies, and tracks language-minority students. In D. J. B. Mitchell (Ed.), California policy options (pp. 145-171). Los Angeles: UCLA Ralph and Goldy Lewis Center for Regional Policy Studies. Retrieved June 2, 2008 from http://www.spa.ucla.edu/ calpolicy/files06/Xiong_Zhou_Policy_Paper_Sept30_2005_Final_1II.pdf 


\begin{abstract}
About the Author
Yang Sao Xiong is a doctoral student in sociology at the University of California, Los Angeles. His recent research examines the effects of state-mandated classification, testing, and tracking on linguistic minority students, especially their access to college-preparatory curricula. His dissertation investigates the emergence and development of ethnicized conflicts and compromise in Hmong American communities.
\end{abstract}




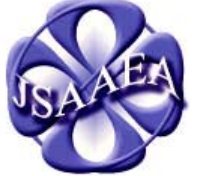

Volume 3

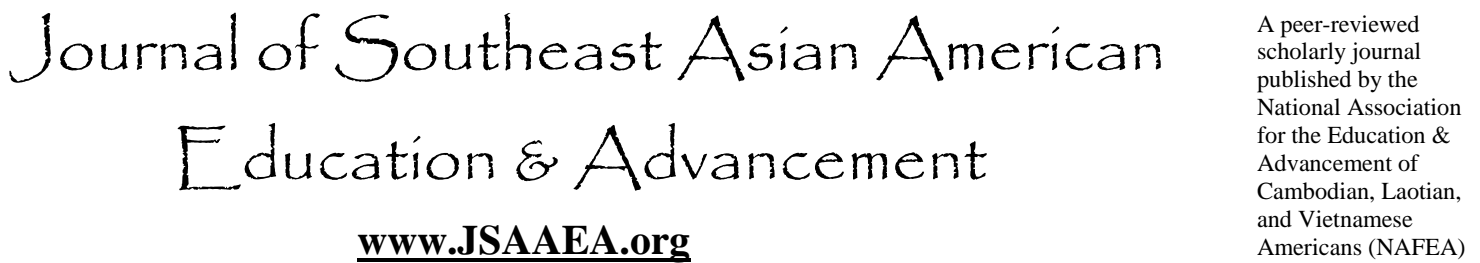

Editor

Dr. Wayne E. Wright

University of Texas, San Antonio

Associate Editors

Dr. Chhany Sak-Humphry

University of Hawaii

Dr. KimOanh Nguyen-Lam

California State University, Long Beach

Book Review Editor

Dr. Leslie Turpin

School for International Training

Creative Works Editor

Phouang Hamilton

Washington Office of Superintendent of Public Instruction

Special Advisor

Anne Frank

University of California, Irvine, Southeast Asian Archives

\section{Editorial Assistant}

Mariana Kuhl

University of Texas, San Antonio

Comments and questions for the editorial staff may be directed to jsaaea@lists.sis.utsa.edu

\section{Editorial Review Board}

\author{
Dr. Carl L. Bankston III \\ Tulane University \\ Dr. Phala Chea \\ Lowell Public Schools \\ Dr. Changming Duan \\ University of Missouri, Kansas City \\ Dr. Nancy H. Hornberger \\ University of Pennsylvania \\ Dr. Peter Nien-Chu Kiang \\ University of Massachusetts, Boston \\ Dr. Stacey Lee \\ University of Wisconsin, Madison
}

\author{
Dr. Pollie Bith-Melander \\ Asian and Pacific Islander Wellness Center \\ Dr. George Chigas \\ University of Massachusetts, Lowell \\ Dr. Sophal Ear \\ U.S. Naval Postgraduate School \\ Dr. Samlong Inthaly \\ Minneapolis Public Schools \\ Dr. Kevin K. Kumashiro \\ University of Illinois, Chicago \\ Dr. David Chanpannha Ley \\ Montgomery County Public Schools
}


Dr. Sue Needham

California State University, Dominguez Hills

Dr. Max Niedzwiecki

Rights Working Group

Dr. Clara Park

California State University, Northridge

Dr. Loan T. Phan

University of New Hampshire

Dr. Karen Quintiliani

California State University, Long Beach

Dr. Fay Shin

California State University, Long Beach

Dr. Yer J. Thao

Portland State University

Dr. Khatharya Um

University of California, Berkeley

Dr. Terrence G. Wiley

Arizona State University
Dr. Bic Ngo

University of Wisconsin-Madison

Dr. Leakhena Nou

California State University, Long Beach

Dr. Mark Pfeifer

Texas A\&M University, Corpus Christi

Dr. Bounlieng Phommasouvanh

Minnesota Department of Education

Dr. Kalyani Rai

University of Wisconsin, Milwaukee

Dr. Nancy J. Smith-Hefner

Boston University

Dr. Myluong Tran

San Diego State University

Dr. Linda Trinh Vo

University of California, Irvine

Dr. Zha Blong Xiong

University of Minnesota

Dr. Kou Yang

California State University, Stanislaus

\section{Doctoral Student Editorial Review Board}

Keo Chea

University of Pennsylvania

Loan Dao

University of California, Berkeley

Ha Lam

Arizona State University

Vanna Som

Harvard University

Giang Pham

University of Minnesota

Tinou Tran

University of Houston, Texas

Phitsamay Sychitkokhong Uy

Harvard University
Vichet Chhuon

University of California, Santa Barbara

Annie BichLoan Duong

San Joaquin County Office of Education

Ravy Lao

University of California, Santa Barbara

Rassamichanh Souryasack

University of California, Santa Barbara

Layheng Ting

State University of New York, Albany

Loan Tran

University of California, Santa Barbara

Yang Sao Xiong

University of California, Los Angeles 